\title{
MALDI-TOF MS and CD Spectral Analysis for Identification and Structure Prediction of a Purified, Novel, Organic Solvent Stable, Fibrinolytic Metalloprotease from Bacillus cereus $\mathbf{B 8 0}$
}

\author{
Rajshree Saxena and Rajni Singh \\ Amity Institute of Microbial Biotechnology, Amity University, Sector 125, Noida, Uttar Pradesh 201303, India \\ Correspondence should be addressed to Rajni Singh; rsingh3@amity.edu
}

Received 28 February 2014; Revised 25 August 2014; Accepted 30 September 2014

Academic Editor: Noomen Hmidet

Copyright (C) 2015 R. Saxena and R. Singh. This is an open access article distributed under the Creative Commons Attribution License, which permits unrestricted use, distribution, and reproduction in any medium, provided the original work is properly cited.

\begin{abstract}
The ability to predict protein function from structure is becoming increasingly important; hence, elucidation and determination of protein structure become the major steps in proteomics. The present study was undertaken for identification of metalloprotease produced by Bacillus cereus B80 and recognition of characteristics that can be industrially exploited. The enzyme was purified in three steps combining precipitation and chromatographic methods resulting in 33.5\% recovery with 13.1-fold purification of enzyme which was detected as a single band with a molecular mass of $26 \mathrm{kDa}$ approximately in SDS-PAGE and zymogram. The MALDI-TOF MS showed that the enzyme exhibited 70-93\% similarity with zinc metalloproteases from various strains Bacillus sp. specifically from Bacillus cereus group. The sequence alignment revealed the presence of zinc-binding region VVVHEMCHMV in the most conserved $\mathrm{C}$ terminus region. Secondary structure of the enzyme was obtained by CD spectra and I-TASSER. The enzyme kinetics revealed a Michaelis constant $\left(K_{m}\right)$ of $0.140 \mu \mathrm{mol} / \mathrm{ml}$ and $V_{\max }$ of $2.11 \mu \mathrm{mol} / \mathrm{min}$. The application studies showed that the enzyme was able to hydrolyze various proteins with highest affinity towards casein followed by BSA and gelatin. The enzyme exhibited strong fibrinolytic, collagenolytic, and gelatinolytic properties and stability in various organic solvents.
\end{abstract}

\section{Introduction}

Proteases are recognized by their catalytic type, that is, aspartic, cysteine, metallo, serine, threonine, and the newly identified asparagine peptide lyases [1]. Metalloproteases are the class of hydrolases that cleave peptide bonds by action of a water molecule which is activated by bivalent metal ions like zinc, cobalt, manganese, or nickel. The water molecule serves as a nucleophile in catalysis and also coordinates with the metal ion as a fourth ligand [2]. The catalytic metal ion is usually coordinated by three conserved amino acid side chain ligands that can be His, Asp, Glu, or Lys amino acid and at least one other residue, which may play an electrophilic role [3].

Metalloproteases exhibit deviant physiological and biochemical properties that account for their therapeutical, pathophysiological, and industrial applications. They are implicated in diseases such as arthritis, cancer, cardiovascular diseases, nephritis, central nervous system disorders, and fibrosis [2]. Enzymes with fibrinolytic and collagenolytic properties have been directly employed in clinical therapy, in the regulation of cellular fibrinolysis, prevention, and cure of thrombotic diseases, as antimicrobial agents for removal of necrotic tissue from burns, wound healing, ulcers, treatment of sciatica and herniated intervertebral discs, isolation of pancreatic islets for transplantation, treatment of Dupuytren's disease, and so forth $[4,5]$.

The study, elucidation, and determination of protein structure have become increasingly vital in proteomics as the structural configuration of the protein significantly contributes towards its functionality. Identification of any enzyme, its active site, and substrate binding region is paramount in finding its application in medicinal and therapeutic fields. In traditional protein chemistry, proteins were identified by de novo sequencing using automated Edman degradation which is based on successive removal of $\mathrm{N}$ terminal amino acids by chemical methods [6]. However since the last decade, this technique has been ousted by 
mass spectrometry, which has emerged as the most powerful analytical tool for protein and peptide identification in protein chemistry due to increased sensitivity (femto mole level) and 10-fold increase in speed [7]. Peptide identification using mass spectrometry is based on a simple principle where a peptide is ionized and the peptide bonds are fragmented in an MS-MS spectrometer. Each resulting fragment ion forms a peak in the spectrum at the corresponding mass to charge $(\mathrm{m} / z)$ ratio of the ions which are obtained as peptide masses spectra or the peptide mass fingerprint (PMF) that contain sequence information characteristic of its generating peptide [8]. PMF obtained from MS studies is compared with the theoretical peptide masses of proteins stored in databases by means of mass search programs generating a score for each $m / z$ comparison or using fragmentation data $[8,9]$.

In the present work, metalloprotease produced by Bacillus cereus B80 was purified and analyzed using MALDI mass spectrometry and its phylogenetic relationship was explored. The secondary structure of the enzyme was studied by CD spectrometry and predicted by I-TASSER. The enzyme was characterized with respect to its various hydrolytic activities and stability to find a potential industry for its exploitation.

\section{Materials and Methods}

2.1. Microbial Strain and Enzyme Production. A newly identified Bacillus cereus B80 strain (NCBI accession number JQ040533) was selected for the present study. The enzyme was produced in statistically optimized media containing $(\mathrm{g} / \mathrm{l})$ sucrose, 5.0; bactopeptone, 50.0; beef extract, 20.0; casein, 20.0; yeast extract, 20.0; and $\mathrm{NaCl}, 10.0$, with $3 \%$ inoculum, incubated for $72 \mathrm{~h}$ at $180 \mathrm{rpm}$ [10]. The fermented broth was centrifuged at $15,000 \mathrm{rpm}$ for $15 \mathrm{~min}$ to remove particulate material. The clear supernatant was used as the crude enzyme.

2.2. Protease and Protein Estimation. Protease production was assayed in terms of protease activity observed using casein as substrate [11]. One unit of protease activity was defined as the amount of enzyme required to liberate $1 \mu \mathrm{g} / \mathrm{mL}$ tyrosine in $1 \mathrm{~min}$ under the experimental conditions.

Protein was quantified according to Bradford's method [12]. The experiments were carried out in triplicate and standard error was calculated.

2.3. Enzyme Purification. Chilled ethanol (95\%) was added to the enzyme supernatant at $1: 2$ concentrations and kept at $-20^{\circ} \mathrm{C}$ overnight. The mixture was centrifuged at $15,000 \mathrm{rpm}$ for $20 \mathrm{~min}$ at $4^{\circ} \mathrm{C}$. The supernatant was subjected to freeze drying for ethanol removal and applied on Sephadex-G75 column $(50 \times 15 \mathrm{~mm}$; Sigma Aldrich) equilibrated with TrisHCL buffer ( $\mathrm{pH}$ 7.5) and eluted in the same buffer at a flow rate $1.0 \mathrm{~mL} / \mathrm{min}$. The active fractions eluted from the gel filtration column were pooled and subjected to Q Sepharose column $(65 \times 10 \mathrm{~mm}$; Sigma Aldrich) preequilibrated with glycine $\mathrm{NaOH}$ buffer ( $\mathrm{pH}$ 9). The fractions were eluted with a linear gradient of $0-1 \mathrm{M} \mathrm{NaCl}$ in glycine $\mathrm{NaOH}$ buffer at a flow rate of $1.0 \mathrm{~mL} / \mathrm{min}$.
For all the purification steps, the sample fractions were assayed for protein content and protease activity using casein as substrate. The enzyme recovery and fold purification were calculated in terms of specific activity.

\subsection{Effect of Temperature and $\mathrm{pH}$ on Enzyme Activity and} Stability. The optimum temperature and $\mathrm{pH}$ of the enzyme activity were examined by varying the incubation temperature from $30^{\circ} \mathrm{C}$ to $70^{\circ} \mathrm{C}$ (at $\mathrm{pH} 9$ for $10 \mathrm{~min}$ ) and performing the assay with phosphate buffer ( $\mathrm{pH}$ 6-7) and glycine$\mathrm{NaOH}$ buffer ( $\mathrm{pH} 8-10)$. To study the thermal stability, the enzyme was incubated at temperatures from $30^{\circ} \mathrm{C}$ to $70^{\circ} \mathrm{C}$ for $2 \mathrm{~h}$ without the substrate fractions. Enzyme samples were withdrawn at every $30 \mathrm{~min}$ and assayed for activity under standard conditions. The stability of the enzyme at different $\mathrm{pH}$ values was assessed by incubating the enzyme in different buffers (as above) for $2 \mathrm{~h}$ without the substrate fractions and the enzyme activity was assessed at every 30 min under standard conditions.

2.5. Electrophoretic Analysis. In order to determine purity and molecular mass of the purified protein, SDS-PAGE was carried out as described by Laemmli [13] using $12 \%$ polyacrylamide resolving gel. The gel was silver stained [14] to visualize the protein bands. Furthermore Casein and gelatin zymography were performed according to the modified method described by Garcia-Carreno et al. [15]. Casein [0.2\% $(\mathrm{w} / \mathrm{v})$ with sodium salt]/gelatin $(0.2 \%)$ was copolymerized with $12 \%$ resolving gel. After electrophoresis, the gel was washed successively with Tris-HCL buffer ( $\mathrm{pH} 7.5)$ containing $2.5 \%$ triton $\mathrm{X}-100$ and glycine- $\mathrm{NaOH}$ buffer ( $\mathrm{pH} 9.0$ ). The gel was then incubated in glycine- $\mathrm{NaOH}$ buffer overnight at $37^{\circ} \mathrm{C}$ and stained with coomassie brilliant blue R-250.

2.6. Identification of Metalloprotease by MALDI Mass Spectrometry. The purified protein bands obtained in SDS-PAGE were excised, subjected to in-gel trypsin digestion. The resulting digests were analyzed by matrix-assisted laser desorption ionization-time of flight mass spectrometry (MALDI-TOF MS; AB SCIEX TOF/TOF 5800 with LC-MALDI). The $m / z$ spectra representing the monoisotopic masses of the digested protein fragments were acquired in the MS and MS/MS modes and analyzed by ProteinPilot Software. These peptide mass values were searched against the published databases (NCBInr, SwissProt) using peptide database search engines as MASCOT, Profound, Sequest, Omssa, and PepFrag to obtain information about the identity of the protein. Searches were performed with a minimum mass accuracy of $50 \mathrm{ppm}$ for the parent ions, an error of $0.3 \mathrm{Da}$ for the fragments, one missed cleavage in the peptide masses, and carbamidomethylation of Cys and oxidation of Met as fixed and variable amino acid modifications, respectively. The confidence threshold for protein identification was set to $95 \%$. The obtained protein sequence was aligned with the similar proteins using "ClustalW" (from EMBL-EBI) for determination of homology or similarity with other reported sequences [16]. Conserved domains and active site in the sequence were identified through NCBI and Prosite from exPASy, respectively. 
TABle 1: Purification steps for metalloprotease.

\begin{tabular}{lccccc}
\hline & Activity $(\mathrm{U})$ & Protein $(\mathrm{mg})$ & Sp. activity U/mg & Recovery & Fold purification \\
\hline Crude enzyme & 31773.5 & 117.12 & 271.29 & 100 & 1 \\
EtOH treated & 31773.1 & 87.2 & 364.76 & 100 & 1.34 \\
Sephadex & 15682.7 & 10.4 & 1507.95 & 39.35 & 5.55 \\
Q Sepharose & 10668.9 & 3 & 3556.3 & 33.577 & 13.10 \\
\hline
\end{tabular}

A dendogram was constructed to analyze the phylogenetic relation of the newly identified protein.

2.7. Circular Dichroism of Metalloprotease. To assess the correct conformation of the new metalloprotease UV circular dichroism (CD) spectrum of the protein was acquired. The far-UV CD spectra in a wavelength range of 190-260 $\mathrm{nm}$ were recorded on a circular Dichroism spectrometer with Stop Flow (Applied PhotoPhysics Chirascan; AIRF-JNU, Delhi) in a 1-mm path length cuvette. $C D$ spectra were run with a stepresolution of $1 \mathrm{~nm}$, an integration time of $5 \mathrm{sec}$, and slit width of $0.6 \mathrm{~nm}$, at $37 \mathrm{uC}$. The spectra were averaged over two scans and corrected by subtraction of the buffer signal. Data are expressed as the mean residue molar ellipticity (MRE) in deg $\mathrm{cm}^{2} \mathrm{dmol}^{-1}$ defined as

$$
\mathrm{MRE}=\frac{M \theta_{\lambda}}{10 d c r},
$$

where $M$ is the molecular weight of the protein, $\theta_{\lambda}$ is $\mathrm{CD}$ in millidegree, $d$ is the path length in $\mathrm{cm}, c$ is the protein concentration in $\mathrm{mg} / \mathrm{mL}$, and $r$ is the number of amino acid residues in the protein. The secondary structure contents were calculated by online software K2D2 ( http://k2d2.ogic.ca/) used for analysis of the obtained spectrum to quantify alpha helix, beta sheets, and random coils.

2.8. Structure Prediction of Metalloprotease. Structure of the new enzyme was predicted by submitting the deduced protein sequence to the automated I-TASSER service (http:// zhanglab.ccmb.med.umich.edu/I-TASSER/) which uses multiple PDB structures depending on its structural conservation, to model different parts of protein. The best model was selected from output based on C-score.

2.9. Enzyme Kinetics Studies. The effect of incubation time, enzyme concentration, and substrate concentration on casein hydrolysis was studied. The kinetic parameters of the enzyme were determined by measuring the enzyme activity at different substrate concentrations $(0-50 \mathrm{mg})$. The $K_{m}$ and $V_{\max }$ values were determined using Michaelis-Menten equation and the Lineweaver-Burk double-reciprocal graph was plotted with the calculated values.

2.10. Substrate Specificity Studies. Various soluble protein substrates (gelatin, casein, azocasein, BSA, keratin, and collagen) at $1 \%$ concentration were assayed for their activity with the purified enzyme.

2.11. Effect of $\mathrm{NaCl}$ on Enzyme Activity at Different $\mathrm{pH}$ Values. Aliquots of the enzyme were mixed with $\mathrm{NaCl}(5 \mathrm{mM}$ and
$10 \mathrm{mM}$ ) at different $\mathrm{pH}$ values (6-10) and the activity was assayed under standard conditions.

2.12. Fibrinolytic Assay and Activity. The fibrinolytic activity of the purified enzyme was performed according to the method of Astrup and Müllertz [17]. Fibrin plates of $1 \mathrm{~mm}$ thickness containing agarose $1.2 \%$, fibrinogen $0.4 \%$, and thrombin $20 \mathrm{U} / \mathrm{mL}$ were prepared. Sample was loaded in the well made on the plate. Distilled water and plasmin were taken as blank and positive control, respectively. The plates were incubated overnight at $37^{\circ} \mathrm{C}$ and observed.

Quantitative estimation of the fibrinolytic activity was performed by modified method of Datta et al. [18]. Fibrinolytic activity was quantified in comparison to the standard curve plotted using known concentrations of plasmin against its absorbance at $275 \mathrm{~nm}$. One fibrinolytic unit (FU) was defined as the amount of enzyme required to increase the absorbance by 0.01 per min.

2.13. Collagenolytic and Gelatinolytic Activity. Collagenolytic/gelatinolytic activity was studied on collagen/gelatin plates of $2 \mathrm{~mm}$ thickness containing (\%) agarose, 1.0 and collagen/gelatin, 1.0. Sample was loaded in the well bored on the plates and the plates were then incubated at $37^{\circ} \mathrm{C}$. After $24 \mathrm{~h}$ the plates were flooded with coomassie blue R250 staining solution for visualization of the clear zones.

2.14. Stability in Organic Solvents. Purified protease was incubated with $50 \%(\mathrm{v} / \mathrm{v})$ organic solvents (hexane, acetone, butanol, ethyl benzene, xylene, benzene, chloroform, amyl alcohol, ethanol, acetonitrile, toluene, DMSO, propanol, and glycerol) at $37^{\circ} \mathrm{C}$ with constant shaking $(120 \mathrm{rpm})$ for 10 days. Samples were removed at every $24 \mathrm{~h}$ and the residual activity was estimated. Sample without any solvent served as control and enzyme control activity at day 1 was taken as $100 \%$.

\section{Results}

3.1. Enzyme Purification. The enzyme was purified to 1.3fold showing $100 \%$ recovery after ethanol treatment. Further purification of the enzyme with Sephadex gel filtration column resulted in 5.55 -fold purification and $49.35 \%$ recovery. In the final step of purification with Q Sepharose ion exchange column, the enzyme was purified to 13.1 -fold with $33.5 \%$ recovery (Table 1).

3.2. Effect of Temperature and $p H$ on Enzyme Activity and Stability. The highest enzyme activity was detected at $60^{\circ} \mathrm{C}$ (Figure 1(a)), while it was stable for $2 \mathrm{~h}$ at $30^{\circ} \mathrm{C}$. At $40^{\circ} \mathrm{C}$ and $50^{\circ} \mathrm{C}$, the enzyme lost only $16-22 \%$ of its activity after $2 \mathrm{~h}$. At $60^{\circ} \mathrm{C}$, the enzyme retained 70 and $44 \%$ of its activity after 

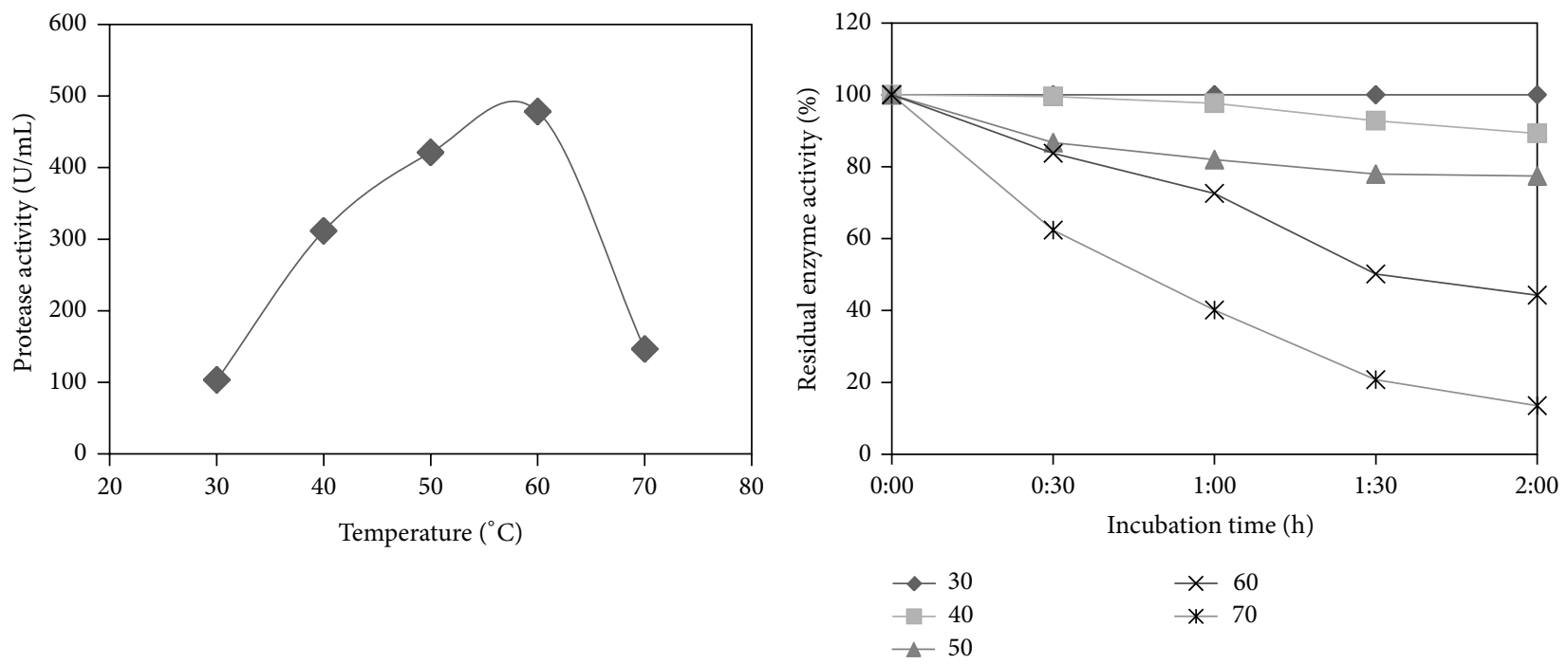

(a)
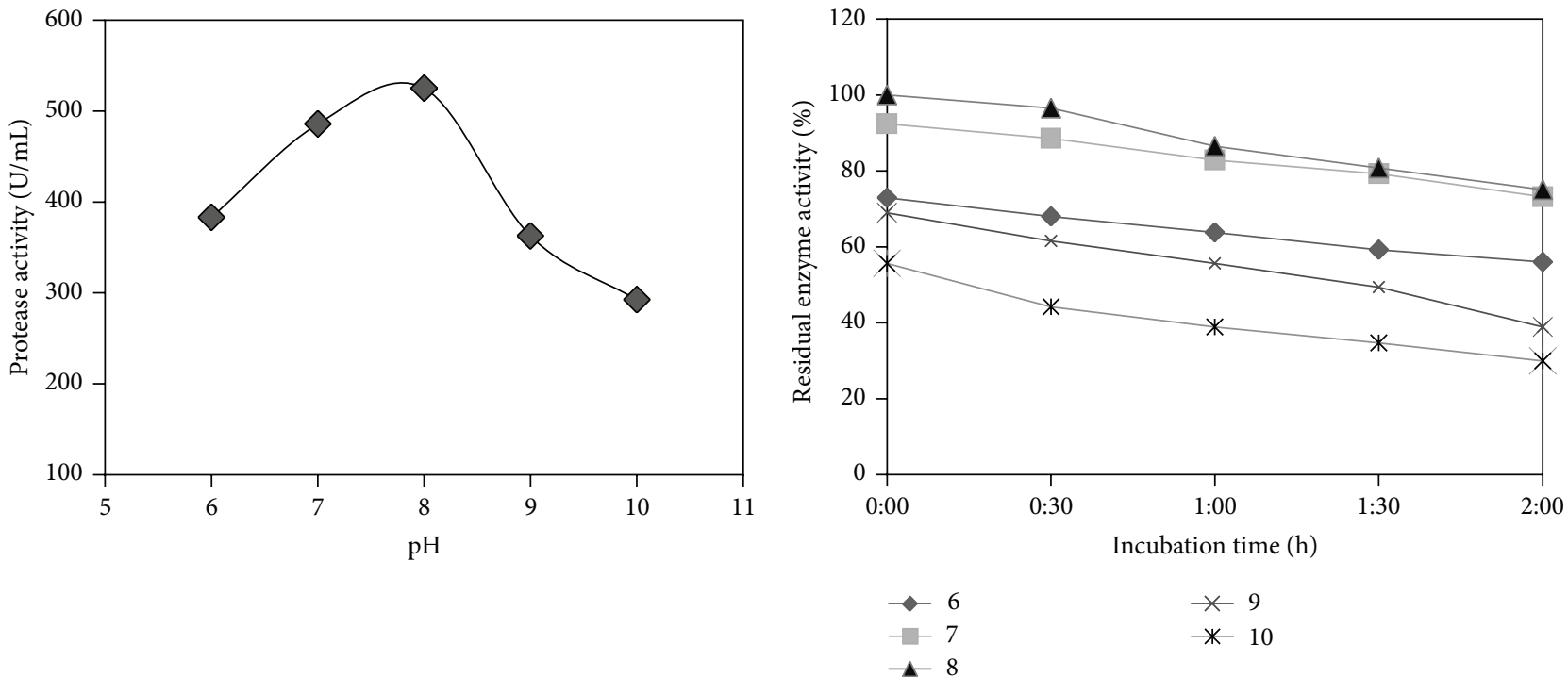

(c)

(d)

Figure 1: (a) Enzyme activity at different temperatures $\left[30^{\circ} \mathrm{C}\right.$ to $\left.70^{\circ} \mathrm{C}\right]$, (b) stability of enzyme at temperatures from $30^{\circ} \mathrm{C}$ to $70^{\circ} \mathrm{C}$, (c) enzyme activity at different $\mathrm{pH}$ values [6 to 10], and (d) stability of enzyme at $\mathrm{pH}$ 6-10.

$1 \mathrm{~h}$ and $2 \mathrm{~h}$, respectively. At $70^{\circ} \mathrm{C}$, the enzyme retained $50 \%$ of its activity (Figure 1(b)). The enzyme was active between $\mathrm{pH} 6.0$ and $\mathrm{pH} 9.0$ with maximum activity at $\mathrm{pH} 8.0$ when incubated for $10 \mathrm{~min}$ at $60^{\circ} \mathrm{C}$ (Figure $1(\mathrm{c})$ ). Within this range the enzyme retained about $75-80 \%$ of the initial activity, while at pH 10 the enzyme retained about $60 \%$ of its initial activity (Figure $1(\mathrm{~d})$ ).

3.3. SDS-PAGE and Zymography Metalloprotease. The purified protein was detected as a single band with a molecular mass of $26 \mathrm{kDa}$ approximately in SDS-PAGE (Figure 2(a)), which corelated with the clear hydrolytic bands observed in casein and gelatin zymogram (Figures 2(b) and 2(c)).
3.4. Metalloprotease Identification Using MALDI Mass Spectrometry. The MALDI TOF MS analysis of the tryptic digested enzyme generated a spectrum of peaks representing the $\mathrm{m} / \mathrm{z}$ ratio of each peptide fragment (Figure 3(a)). Automated analysis of the spectra was performed by software Protein Prospector Auto MS-Fit. Five major peptides were further analyzed on nanospray TOFMS/MS which fragmented the peptides into $\mathrm{y}$ and $\mathrm{b}$ ions, indicating the best matching peptide sequences (Figure 3(b)).

3.5. Database Search. The PMF searches with MASCOT search engine showed matching of six values (1308.69, $2186.07,1251.66,862.38,830.41,1324.69$, and 1641.8) with 
TABle 2: The peptide matching (12/16 matches) for $\mathrm{m} / \mathrm{z}$ data of metalloprotease with zinc metalloprotease from Bacillus cereus (gi|507041200|ref|WP_016112858.1|).

\begin{tabular}{lcccccc}
\hline Spectrum & $\begin{array}{c}\text { Prec. } \\
m / z\end{array}$ & $\begin{array}{c}\text { MH+ } \\
\text { Matched }\end{array}$ & Modifications & Missed cleavages & Position & Peptide \\
\hline 1.F2.2.1.5 & 2704.8679 & 2761.3123 & MSO & 0 & $1-23$ & MIHTYLGETINFHINCKKKKSVR (I) \\
1.F2.2.1.7 & 2383.300 & 2446.1576 & CYS_CAM MSO & 0 & $187-206$ & (R) VIDYVVVHEMCHMVHLNHDR (S) \\
1.F2.2.1.9 & 1638.686 & 1617.8601 & MSO & 1 & $39-51$ & (K) GTPVEYVLQLLEEK (W) \\
1.F2.2.1.15 & 1052.532 & 979.1244 & CYS_CAM MSO & 0 & $129-135$ & (R) FYYQQCK (A) \\
1.F2.2.1.12 & 1350.614 & 1314.5724 & & 0 & $61-73$ & (K) EMKRVLGPQEK (V) \\
1.F2.2.1.13 & 1267.53 & 1260.4618 & MSO & 0 & $52-61$ & (K) WDWIQKTRK (E) \\
1.F2.2.1.16 & 868.4659 & 887.0877 & MSO & 0 & $136-143$ & (K) ALVEKSIK (S) \\
1.F2.2.1.3 & 1803.738 & 1786.1747 & CYS_CAM MSO & 0 & $172-186$ & (K) LQLTFNWKLAMAPPR (V) \\
1.F2.2.1.4 & 1707.594 & 1695.8900 & & 0 & $24-38$ & (R) IYIDSYGNVEVQAPK (G) \\
1.F2.2.1.2 & 1765.5551 & 1740.1028 & & 0 & $204-216$ & (R) SFWRLVGKIMPDYK (I) \\
1.F2.2.1.8 & 1838.717 & 1757.0606 & & 0 & $110-123$ & (K) LHIYVKELEDEKIK (Q) \\
1.F2.2.1.1 & 1488.676 & 1494.6884 & MSO & 1 & $221-231$ & (K) EMEDWLALSSWK (M) \\
\hline
\end{tabular}

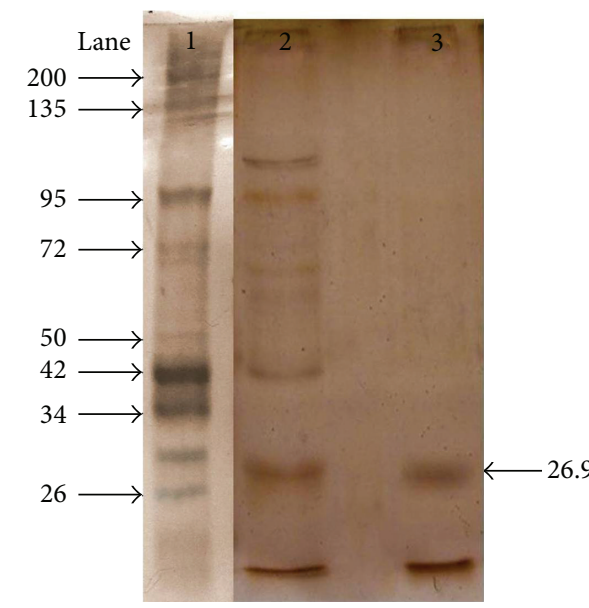

(a)

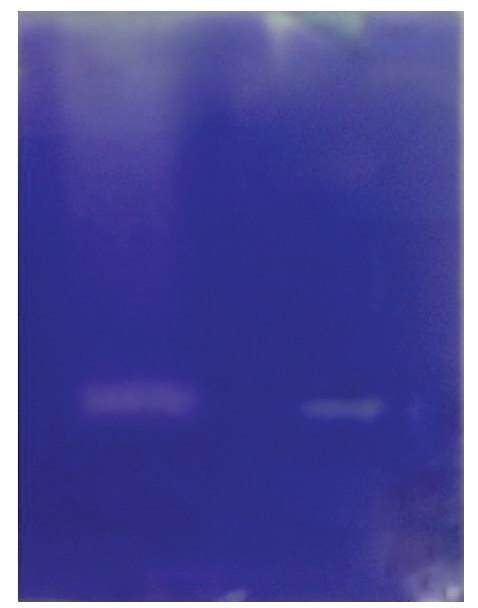

(b)

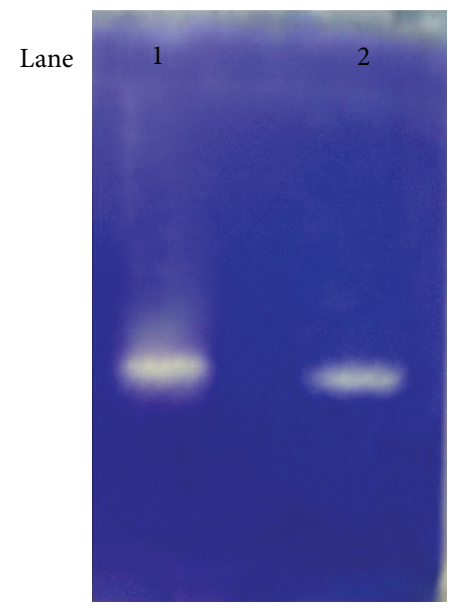

(c)

FIGURE 2: (a) SDS-PAGE of purified metalloprotease. Lane 1: DNA markers of different molecular weights; Lane 2: crude enzyme; Lane 3: purified metalloprotease. (b) Casein zymogram of the purified metalloprotease. Lane 1: Crude enzyme and Lane 2: purified enzyme showing zone of clearance on casein polymerized gel. (c) Gelatin zymogram of the purified metalloprotease. Lane 1: crude enzyme and Lane 2: purified enzyme showing zone of clearance on gelatin polymerized gel.

a statistically significant score of 94 matching hypothetical protein HPHPM1_1713 [Helicobacter pylori Hp M1] (gi|393135873) which demonstrated a score of 24.6 with 22$24 \%$ identity with bacillolysin [Bacillus cereus; gi|401187907] and M6 family metalloprotease domain-containing protein from various Bacillus cereus strains [gi|402425459; gi|507050904; gi|507054527; gi|401287019; gi|401220725]. The database search with Profound, however, yielded more significant results exhibiting 1.0 expectation value with zinc metalloprotease from Bacillus cereus; gi|507041200 and 0.79 expectation value with zinc metalloprotease from Bacillus mycoides Rock3-17 [gi|228995693] and Bacillus mycoides Rock1-4 (gi|229003322) with some unmatched peptides though. The matching of the $\mathrm{m} / z$ data with zinc metalloprotease from Bacillus cereus; gi|507041200 is stated in Table 2 and Figure 4(a). The unmatched peptide masses were further searched in Mascot and Profound. The motif search with Prosite revealed the presence of zinc-binding region VVVHEMCHMV in the most conserved $\mathrm{C}$ terminus region (Figure 4(a)).

3.6. Sequence Homology, Alignment, and Phylogenetic Studies. The sequence homology search performed through NCBI protein blast showed that the purified protein held 90-93\% similarity with zinc metalloproteases from various Bacillus strains that belong to Bacillus cereus group. Thus, the protein was identified as zinc metalloprotease. The protein sequence was found to have three conserved domains DUF45, COG1451, and WLM. DUF45 family includes amino acids 190-240, with $C$ terminus being the most conserved region containing three histidines similar to that found in zinc proteases suggesting that this family may also 


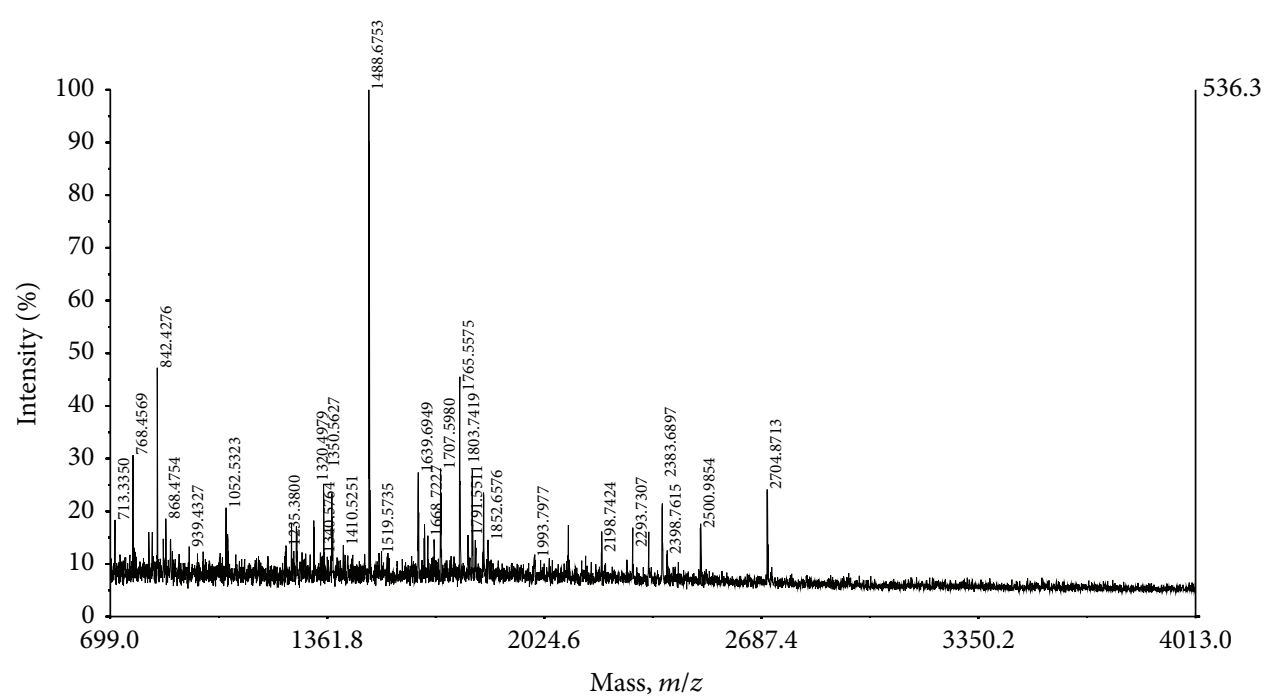

(a)
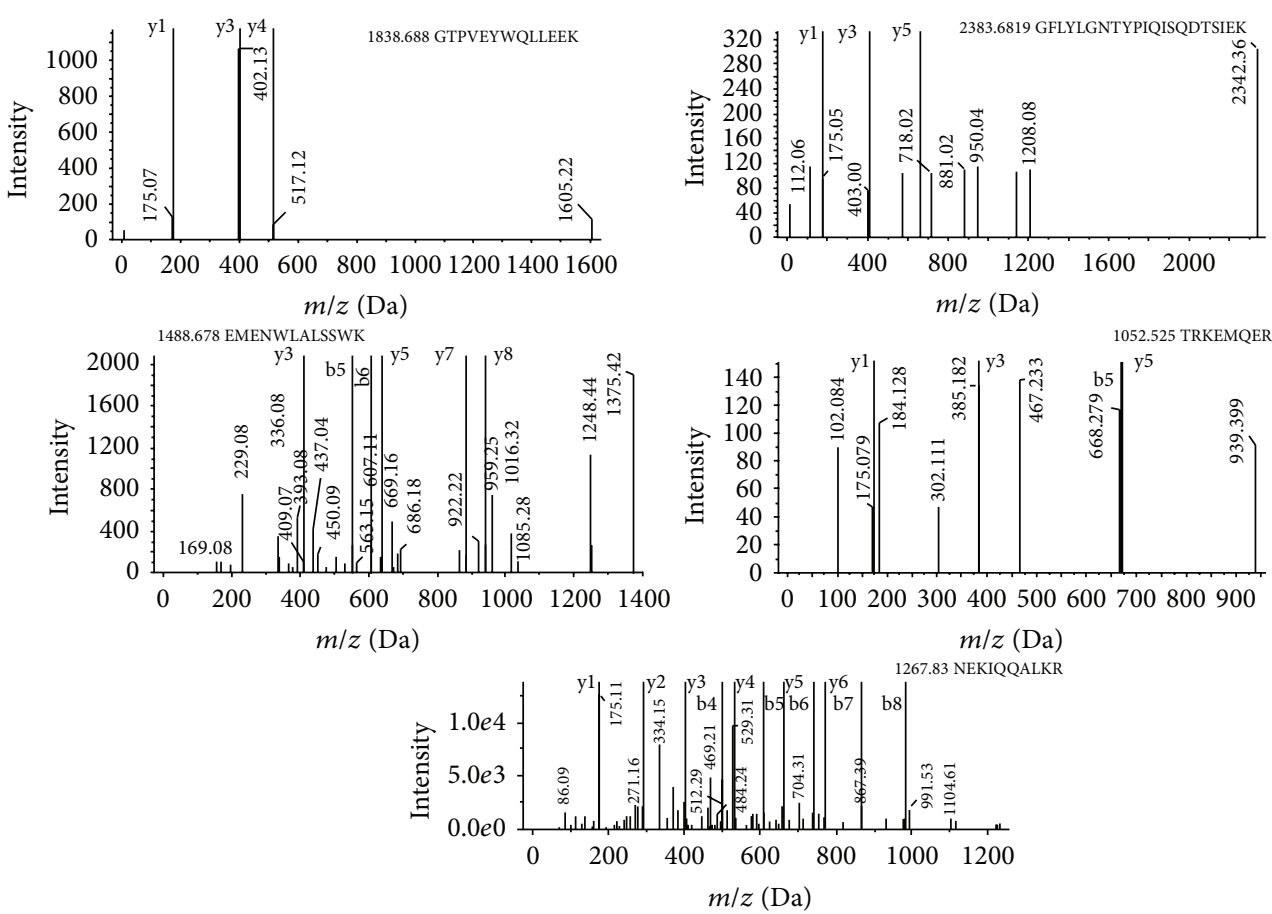

(b)

Figure 3: (a) Peptide mass spectra of the tryptic digested peptides as obtained from MALDI TOF mass spectrometry. (b) Annotated MS/MS spectra of fragmentation of 5 peptides in MS/MS that produce mostly y and $b$ ions. The parent $m / z$ values and the sequence of the identified peptides are indicated.

be proteases. COG1451 includes predicted metal-dependent hydrolase and WLM [pfam 08325] is a predicted metallopeptidase domain called WLM (Wsslp-like metalloproteases). The multiple sequence alignment was performed with known sequences of zinc metalloproteases from various strains belonging to the Bacillus cereus group, zinc metalloprotease from Bacillus cereus [gi|507061435], Bacillus mycoides [gi|489287106], Bacillus mycoides [gi|489298176], and Bacillus weihenstephanensis [gi|501217222]. The alignment demonstrated the similarity of the purified protease with these sequences (Figure 4(b)).
The evolutionary relationship tree (Figure 5) of the new metalloprotease from Bacillus cereus B80 showed homology with zinc metalloprotease from various Bacillus sp.

3.7. Secondary Structure by CD Spectrometry. The CD spectrum of the metalloprotease is represented in Figure 6(a). The spectrum analysis by K2D2 (Figure 6(b)) showed presence of $\alpha$ helix, $36.26 \%$ and $\beta$ strand, $11.68 \%$ with max error more than 0.32 . The analysis showed presence of more $\alpha$ helices than $\beta$ strands. 


\begin{tabular}{|c|c|c|c|c|c|}
\hline 10 & 20 & 30 & 40 & 50 & 60 \\
\hline MIHTYSGKTI & NFHINYKKKK & SVRIYIDSYG & NVEVQAPKGT & PVEYVLQLLE & EKWDWIQKTR \\
\hline $\begin{array}{r}70 \\
\text { KEMKERVLGP }\end{array}$ & $\begin{array}{r}80 \\
\text { QEKVYNQGES }\end{array}$ & $\begin{array}{r}90 \\
\text { FLYLGNTYPI }\end{array}$ & $\begin{array}{r}100 \\
\text { QISQDASIGQ }\end{array}$ & $\begin{array}{r}110 \\
\text { DDAVFEGDKL }\end{array}$ & $\begin{array}{r}120 \\
\text { HIYVKELEDE }\end{array}$ \\
\hline $\begin{array}{r}130 \\
\text { KIKQALKRFY } \\
190\end{array}$ & $\begin{array}{r}140 \\
\text { YQQCKALVEK } \\
200\end{array}$ & $\begin{array}{r}150 \\
\text { SIKSYQSNFK } \\
210\end{array}$ & $\begin{array}{r}160 \\
\text { TKPRSIRISD } \\
220\end{array}$ & $\begin{array}{r}170 \\
\text { SNRTWGTCDS } \\
230\end{array}$ & $\begin{array}{r}180 \\
\text { KLQLTFNWKL }\end{array}$ \\
\hline AMAPPRVIDY & VVVHEMCHMV & HLNHDRSFWR & LVGKIMPDYK & EMEDWLALSS & WKMTV \\
\hline
\end{tabular}

(a)

gi | 489287106 | ref | WP_003194677. gi | 489298176 | ref | WP_003205665. gi | 501217222 | ref | WP_012260240. Unnamed

gi | 507061435 | ref | WP_016132296.

gi | 489287106 | ref | WP_003194677. gi | 489298176 | ref | WP_003205665. gi | 501217222 | ref | WP_012260240. Unnamed

gi | 507061435 | ref | WP_016132296.

gi | 489287106 | ref | WP_003194677. gi | 489298176 | ref | WP_003205665. gi | 501217222 | ref | WP_012260240. Unnamed

gi | 507061435 | ref | WP_016132296.

gi | 489287106 | ref | WP_003194677. gi | 489298176 | ref | WP_003205665. gi | 501217222 | ref | WP_012260240. Unnamed gi | 507061435 | ref | WP_016132296.

gi | 489287106 | ref | WP_003194677. gi | 489298176 | ref | WP_003205665. gi | 501217222 | ref | WP_012260240. Unnamed

gi | 507061435 | ref | WP_016132296.

${ }^{*}$ Unknown purified metalloprotease
M IHTYL GETINFHINYKKKKSVRLYVDSYGNVEVQAPKGTPVEYIIQLLE M IHTYL GETINFHINYKKKKSVRLYVDSYGNVEVQAPKG TPVEYI I LLE MVHTYLGETINFHITYKKKKSVRLFVDSYGNVEVQAPKGTPVEYLVQLLE M IHTYSGKT INFH INYKKKKS VRIYIDSYGNVEVQAPKG TPVEYVLQLLE M IHTYSGKT INFH INYKKKKS VR I I DSYGNVEVQAPK G TPVEYVLQLLE $*: * * * \quad *: * * * * * * . * * * * * * * *:::: * * * * * * * * * * * * * * * * * *:: * * * *$

EKWDWIQKTRKEM QER VLGPQEKAYDQGEGFLYLGNTYPIQISQDTSIEQ 100 EKWDW I QKTRKEM QER VLGPQEKAYDQGKGFLYLGNTYPIQISQDTSIEK 100 EKWDWIQKTRKEM QER ALGPQEKGYDQGEGFLYLGNTYPIQISQDASIEQ 100 EKWDWI QKTRKEMKER VLGPQEKVYNQGESFLYLGNTYPIQISQDASIGQ 100 EKWDWI QKTRKEM KER VLGP QEKVYNQGESFLYLGNTYPIQISQDAGIGQ 100 $* * * * * * * * * * * * *: * *, * * * * * *, * * * ;: * * * * * * * * * * * * * * *:, *$ :

DNA VFEGDKLH I Y K KELKNEK I QQA LKRFYYKQCKA LVEKS IKSYQSNFK DNA VFEGDKLH I Y V KELKNEK I QQA LKRFYYKQCKA LVEKSIKSYQSNFK DNA VFEGDKLH I Y VNELKDEK I QQA LKRFYYKQCKA LVEKS IKAHQSNFK DD A VFEGDKLH I Y VKELEDEK I KQA LKRFYYQQCKA LVEKSIKSYQSNFK D D A VFEGDKLHIYVKELEDEK IKQALKRFYYQQCKA LVEKS IKSYQSNFK *: $: * * * * * * * * * * *: * *:: * * *: * * * * * * * *: * * * * * * * * * * *:: * * * * *$

TKPRLIRISDSNRTWGTCDSNLQLTFNWKLAMAPQRVIDYVVVHEMCHMV 200 TKPRLIR ISDSNRTWGTCDSNLQLTFNWKLAMAPQRVIDYVVVHEMCHMV 200 TKPRSIRITDSSRTWGTCDSNLQLTFNWKLAMAPQRVIDYVVVHEMCHMV 200 TKPRSIRISDSNRTWGTCDSKLQLTFNWKLAMAPPRVIDYVVVHEMCHMV 200 TKPRS IR ISD SNR TWG T D SK L L L F NWKLAMAPPRVIDYVVVHEMCHMV 200 $* * * * \quad * * *: * *, * * * * * * * *: * * * * * * * * * * * * * \quad * * * * * * * * * * * * * * *$

HLNHDRSFWRLVGKIMPDYKEMENWLA LSSWKMTV 235 HLNHDR SFWR LVGKIMPDYKEMENWLA LSSWKMTV 235 HLNHDRSFWRLVGKIMPDYKEMENWLALSSWKMTV 235 HLNHDR SFWR LV GKIMPDYKEMEDWLALSSWKMTV 235

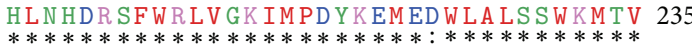

(b)

Figure 4: (a) The peptide sequence of zinc metalloprotease from Bacillus cereus (gi|507041200) showing matching for $m / z$ data of the new metalloprotease (in bold). (b) Multiple sequence alignment of the purified protease with similar known sequences using ClustalW.

3.8. Elucidation of Protein Structure. Five predicted models for the newly sequenced zinc metalloprotease from Bacillus cereus B80 were obtained from I-TASSER (http://zhanglab .ccmb.med.umich.edu/I-TASSER/) [19]. Model 2 with the highest C-score was selected (Figure 6(c)). The estimated accuracy of Model 2 is as follows: $\mathrm{C}$ score: -3.26 , TM-score: $0.26+0.08$, and RMSD: $16.5+3.0 \AA$. C-score is a confidence score for estimating the quality of predicted models by ITASSER, typically in the range from -5 to 2 , where higher value signifies a model with high confidence. TM-score is a recently proposed scale for measuring the structural similarity between two structures. A TM-score $>0.5$ indicates a model of correct topology and a TM-score $<0.17$ means a random similarity [20]. RMSD is an average distance of all residue pairs in two structures.

3.9. Enzyme Kinetics Studies. The rate of reaction for the enzymatic hydrolysis studied by varying incubation time is represented by a hyperbola, where the rate of reaction increased from 0 to $10 \mathrm{~min}$, and thereafter velocity of the reaction remained constant. The $R^{2}$ value of 0.872 validates the study (Figure 7(a)).

The enzyme assay with different aliquots of enzyme $(0.02 \mathrm{~mL}-0.5 \mathrm{~mL})$ is depicted in Figure $7(\mathrm{~b})$. The straight line shows that the reaction velocity increases with the increase in enzyme concentration. $R^{2}$ value of 0.9655 validates the study. 


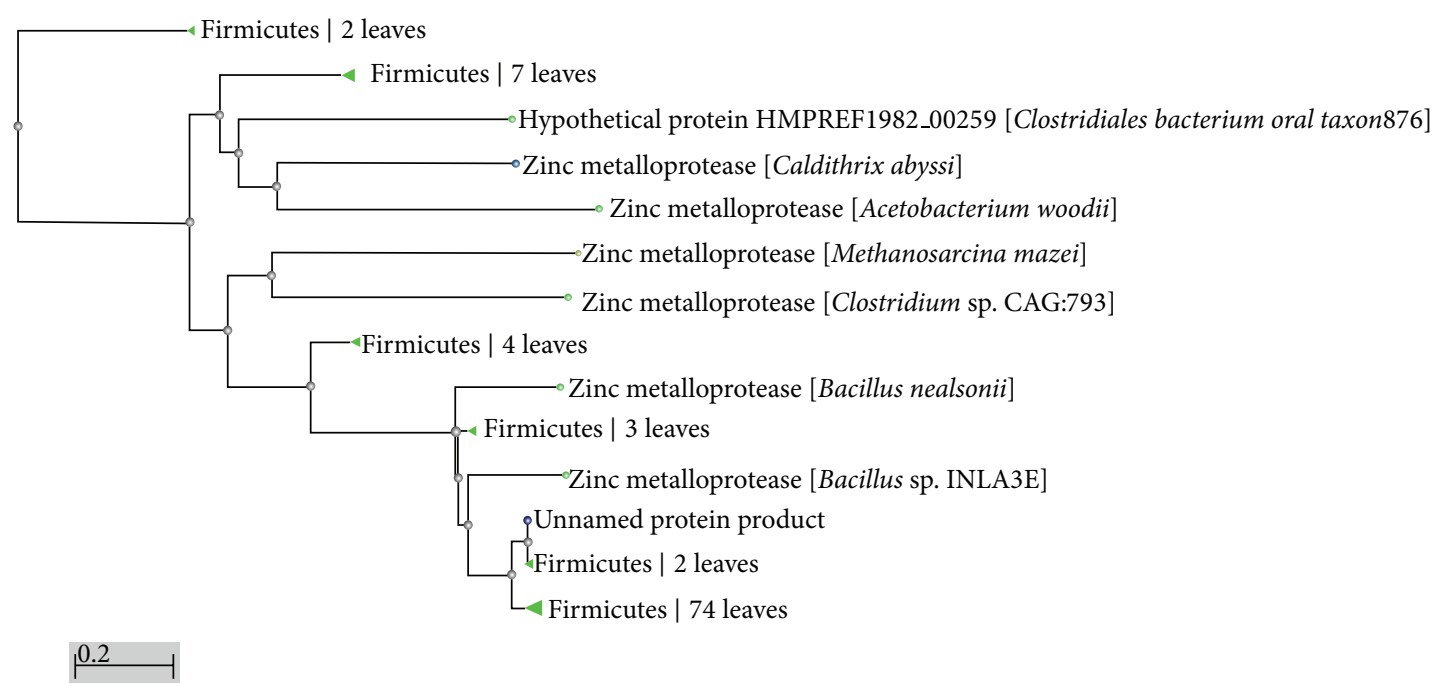

FIgURE 5: Phylogenetic tree of metallprotease from Bacillus cereus B80 with other metalloproteases.

The Michaelis-Menten graph was plotted with reaction velocity $(v)$ as a function of substrate concentration $(S)$ (Figure 7(c)). The kinetic constants values of the purified metalloprotease as obtained from the Michaelis-Menten equation were Michaelis constant $\left(K_{m}\right) 0.140 \mu \mathrm{mol} / \mathrm{ml}$ and $\mathrm{V}_{\max } 2.11 \mu \mathrm{mol} / \mathrm{min}$. The Lineweaver-Burk double-reciprocal plot was prepared with the reciprocal of reaction velocity $(1 / v)$ as a function of reciprocal of substrate concentration $(1 / S)$ (Figure $7(\mathrm{~d})$ ).

3.10. Substrate Specificity Studies. The enzyme was able to hydrolyze all the soluble proteins as gelatin, casein, azocasein, BSA, keratin hydrolyzed, and collagen, with highest affinity towards casein followed by BSA and gelatin (Figure 8(a)).

3.11. Effect of $\mathrm{NaCl}$ on Enzyme Activity. The enzyme activity enhanced in presence of $\mathrm{NaCl}$ at 5 and $10 \mathrm{mM}$ concentrations (Figure 8(b)). This shows that the enzyme is a mild halotolerant protease. It was also observed that $\mathrm{NaCl}$ had no effect on optimum $\mathrm{pH}$ of the enzyme activity as the increase of about $20 \%$ was similar at all $\mathrm{pH}$ values (6-9) with maximum activity at 7.

3.12. Fibrinolytic Activity. The fibrin plates with the positive (plasmin) and the purified enzyme showed a clear transparent region where fibrin was hydrolyzed, after overnight incubation, indicating fibrinolytic activity of the enzyme (Figure 9(a)). The fibrin plate with the metalloprotease exhibited a bigger zone of hydrolysis than the plasmin plate. Control showed no zone of hydrolysis. The quantitative estimation of the fibrinolytic activity of the purified metalloprotease showed 81FU.

3.13. Collagenolytic and Gelatinolytic Activity. The collagen and gelatin plates exhibited a clear zone of hydrolysis on addition of dye after overnight incubation, while the control plates showed no zone of hydrolysis (Figures 9(b) and 9(c)).
3.14. Stability in Organic Solvents. The enzyme was highly stable in most of the solvents for 4 days retaining 100-74\% activity regardless of their $\log P$ values (Table 3 ). The residual activity of enzyme in presence of xylene was $118 \%$, toluene $115 \%$, benzene $83 \%$, ethyl benzene $81 \%$, and amyl alcohol $78 \%$ after 10 days. With acetone, the enzyme was stable with $91 \%$ activity till day 8 , while in presence of DMSO, the enzyme retained $80 \%$ activity till the 6 th day. The enzyme was less stable with glycerol, chloroform, acetonitrile, ethanol, and propanol retaining only $21,18,35,38$, and $28 \%$ activity after 10 days and was least stable with butanol retaining only $20 \%$ activity after 10 days.

The results also showed that the enzyme activity increased from 100 to $172 \%$ in presence of ethyl benzene, $147 \%$ with glycerol, 115, 107 and 106\% with toluene, chloroform, xylene and DMSO, respectively, on day 1 . The activity increased further to $182,189,118,180,154,190,100,110$, and $159 \%$ with xylene, toluene, DMSO, amyl alcohol, butanol, acetonitrile, ethanol, acetone, and propanol-2, respectively.

\section{Discussion}

The three-step purification process of enzyme was followed keeping in view the physicochemical nature of the enzyme and other components present in the media after fermentation. The supernatant obtained after centrifugation appeared to be dense and viscous, which might have been due to the presence of DNA and exopolysaccharides. Protein supernatants are treated with ethanol and isopropanol for reduction in viscosity [21]. Proteins are complex ampholytes that have both positive and negative charges depending upon the proportions of ionizable amino acid residues in its structure. However, in metallo-proteins, an internal metal ion often is coordinated by charged residues and hence the overall charge on the molecule is influenced by the neighboring sidechain groups which give the protein a varying net charge depending on the $\mathrm{pH}$ of the solute, which influences its binding and elution in an ion exchange column [22]. 


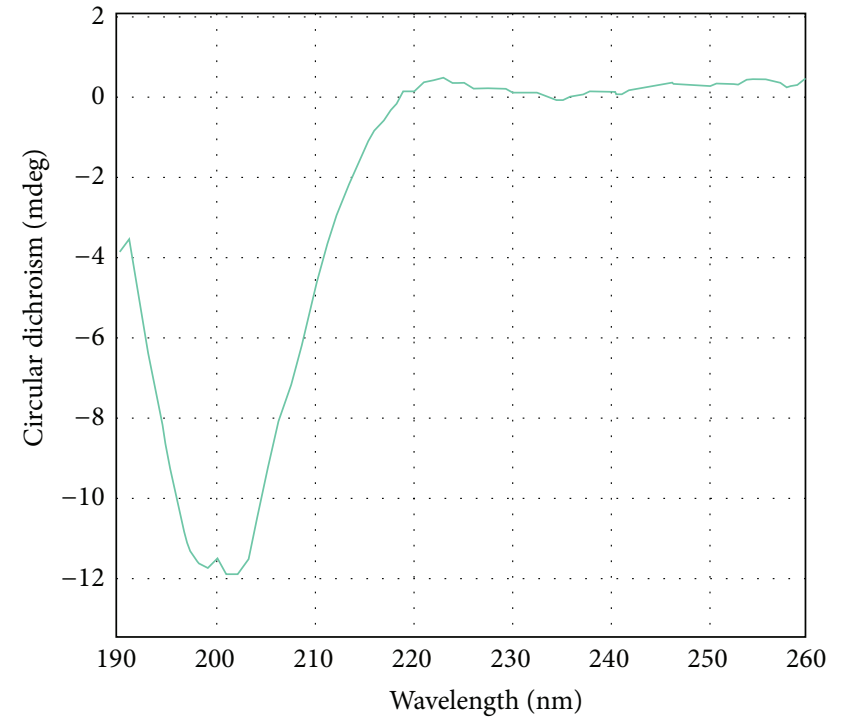

— Smooth (s): 0

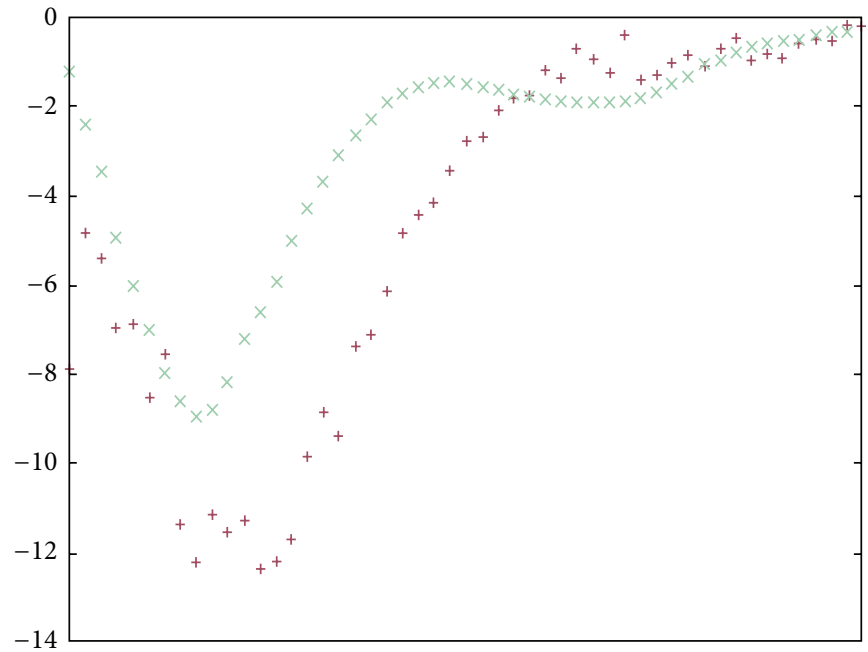

(a)

(b)

Title: Model 2

PDB ID:

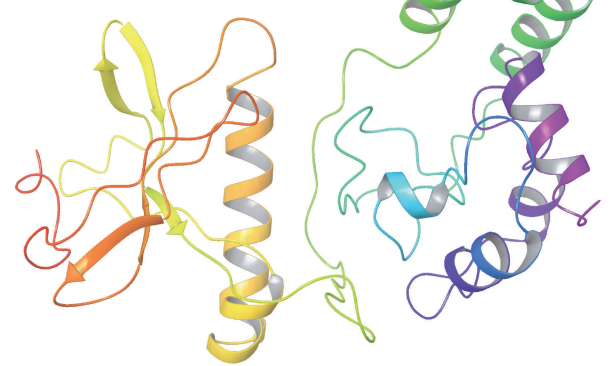

(c)

FIGURE 6: (a) CD spectra of metalloprotease. (b) K2d2 analysis: (+) input spectrum and (x): predicted spectrum of CD spectra. (c) 3D structure (from I-TASSER) of newly identified zinc metalloprotease from Bacillus cereus B80.

TABLE 3: Effects of organic solvents on the stability of the enzyme.

\begin{tabular}{|c|c|c|c|c|c|c|c|}
\hline Solvents & $\log P$ value & Day 1 & Day 2 & Day 4 & Day 6 & Day 8 & Day 10 \\
\hline None & & 100 & 100 & 98.18 & 98 & 96 & 92 \\
\hline Hexane & 3.98 & 99.26 & 81.37 & 96.71 & 51.29 & 40.21 & 38.98 \\
\hline Ethyl benzene & 3.15 & 172.79 & 139.95 & 120.32 & 97.43 & 85.15 & 81.48 \\
\hline Xylene & 3.15 & 106.37 & 182.84 & 176.40 & 160.28 & 132.17 & 118.39 \\
\hline Toluene & 2.73 & 115.69 & 189.22 & 169.01 & 143.20 & 126.54 & 115.94 \\
\hline Benzene & 2.13 & 99.95 & 95.58 & 96.95 & 87.22 & 86.54 & 83.1 \\
\hline Chloroform & 2 & 107.6 & 107.84 & 84.457 & 25.94 & 24.52 & 18.93 \\
\hline Amyl alcohol & 1.2 & 77.21 & 180.88 & 107.00 & 104.13 & 94.67 & 78.67 \\
\hline Butanol & 0.88 & 94.12 & 154.41 & 125.35 & 104.13 & 14.04 & 8.41 \\
\hline Propanol 2 & 0.074 & 99.50 & 159.8 & 74.89 & 51.29 & 32.66 & 28.44 \\
\hline Acetone & -0.21 & 90.93 & 110.05 & 98.42 & 96.68 & 91.49 & 51.72 \\
\hline Ethanol & -0.235 & 85.29 & 100.24 & 88.62 & 61.53 & 50.07 & 38.98 \\
\hline Acetonitrile & -0.394 & 94.85 & 190.2 & 96.71 & 84.23 & 54.72 & 35.74 \\
\hline DMSO & -1.378 & 106.62 & 118.63 & 115.82 & 80.84 & 69.77 & 52.49 \\
\hline Glycerol & -1.93 & 147.30 & 95.83 & 93.77 & 85.11 & 76.54 & 21.58 \\
\hline
\end{tabular}




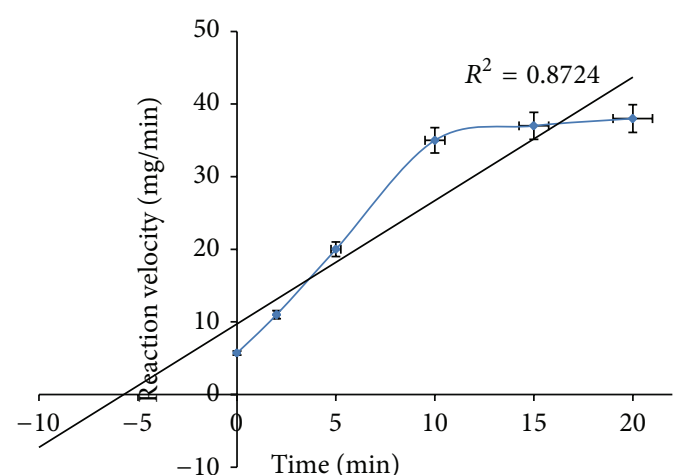

(a)

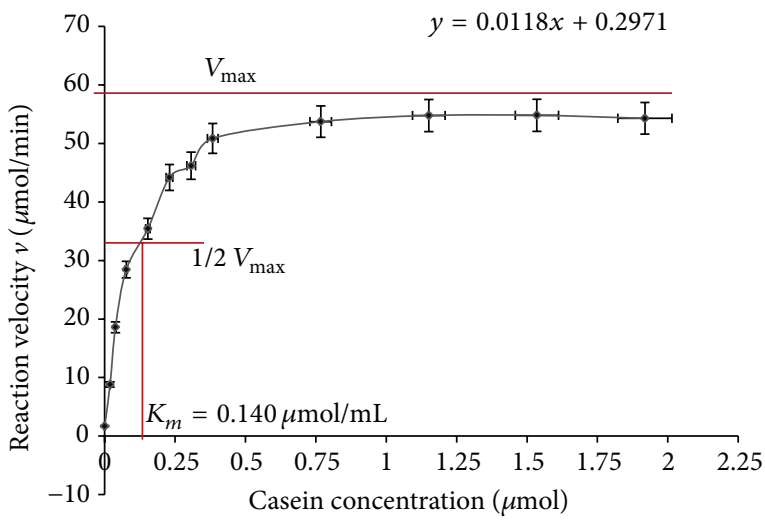

(c)

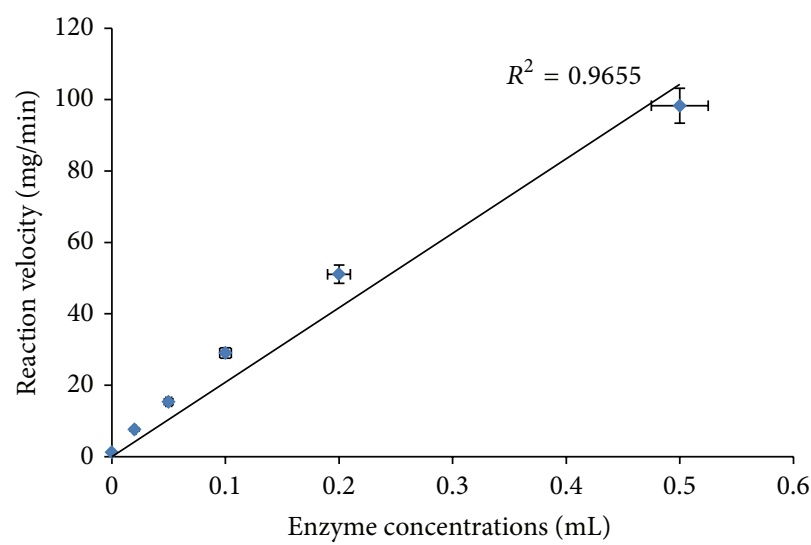

(b)

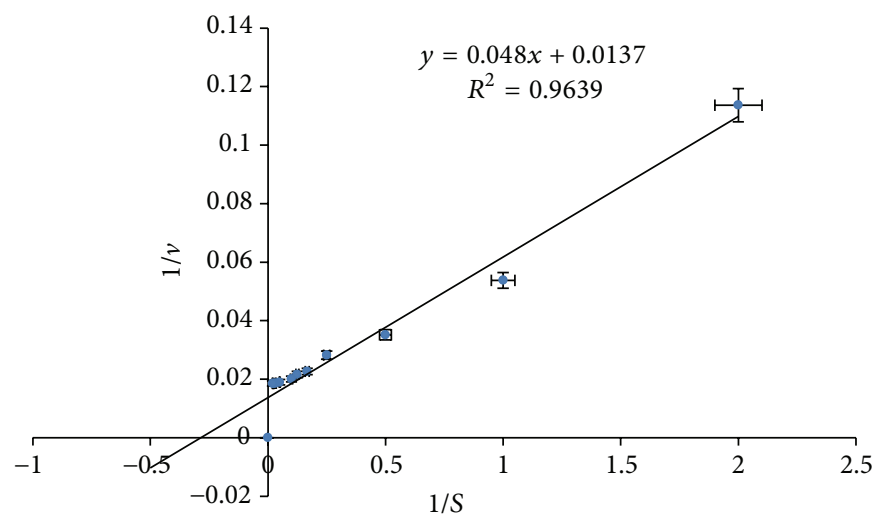

(d)

Figure 7: (a) Effect of incubation time on Casein hydrolysis. (b) Effect of enzyme concentration on Casein hydrolysis. (c) Enzyme kinetics, Michaelis-Menten Menton graph and (d) Lineweaver-Burk Plot.

The $\mathrm{pH}$ and temperature profile of the enzyme demonstrates that the enzyme is $\mathrm{pH}$ and thermostable. Proteases with similar thermostability, $\mathrm{pH}$ activity, and stability enzymes have been reported by [23-25], where the enzyme retained $100-80 \%$ activity only for $30 \mathrm{~min}$ in temperatures from 35 to $60^{\circ} \mathrm{C}$, while in our study the enzyme retained $100-$ $70 \%$ activity after $1 \mathrm{~h}$ at $30-70^{\circ} \mathrm{C}$ demonstrating its unique thermostability at high temperatures.

The masses of the peptide fragments as obtained by MALDI TOF MS were typically constrained between 600 and $3000 \mathrm{Da}$ relating to that the digested protein is of smaller molecular weight [8]. The amino acids modifications alter the residue mass (protein), possibly making the modified peptide more or less readily ionized, hydrophilic, or soluble. Sometimes, a chemical bond that is particularly labile to mass spectrometric fragmentation is introduced into the peptide sequence that makes the fragmentation of the peptide easier. However this results in increased number of false positives (incorrect identifications) and false negatives (missed true identifications), during identification of peptides. The error is minimized by employing Tandem mass spectrometry (MS/MS) that detects the fragmented ions in the spectra, thereby identifying the amino acid modification and peptide identification [26].
Significant $m / z$ matchings were obtained in the database searching; however, some peptides exhibited no significant matching. High quality spectra may show unidentified peptides in a typical data analysis due to several reasons like smaller number of peptides generated due to improper digestion of protein, inaccurate charge state or precursor ion $\mathrm{m} / \mathrm{z}$ measurement, constrained database search parameters, presence of chemical or posttranslational modifications, and incompleteness of the protein sequence database [27]. The presence of VVVHEMCHMV peptide in the most conserved region identifies the new enzyme as zinc metalloprotease. The majorities of zinc-dependent metallopeptidases share a sequence similarity and common pattern of primary structure in the zinc-binding region and can be grouped together as a superfamily known as the metzincins [3].

Secondary structure analysis by circular dichroism (CD) spectroscopy revealed presence of more $\alpha$ helices and random coils than $\beta$ sheets. Protein CD spectra result in large part from peptide transitions associated with secondary structural components such as alpha (the alpha-helix is a $3.6_{13}$ helix), $3_{10}$ and $4.4_{16} \cdot 3_{10}$ (other common helical conformations), polyproline-II helices, and parallel and antiparallel b-sheets. These produce characteristic CD spectral features in the ultraviolet (UV) wavelength regions through distinct interactions with the left and right circularly polarized light from 


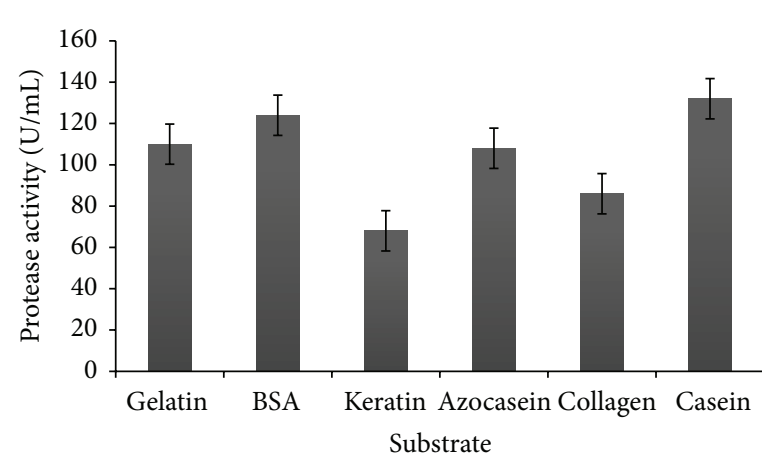

(a)

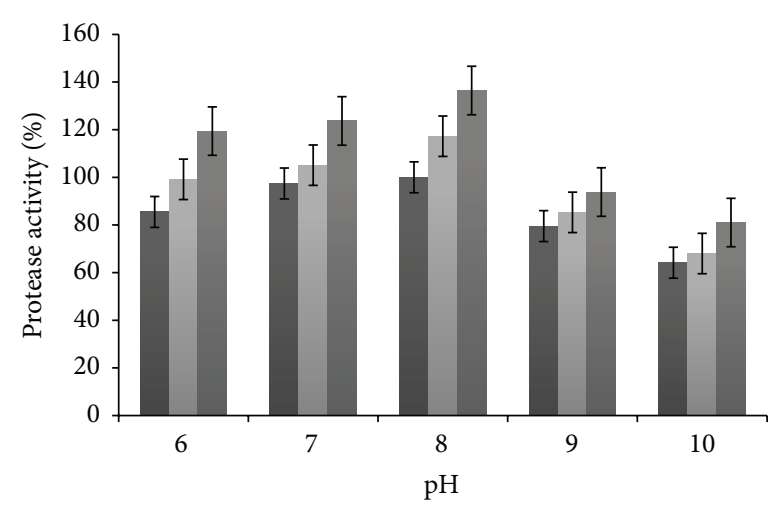

- Crude

- $5 \mathrm{mM} \mathrm{NaCl}$

- $10 \mathrm{mM} \mathrm{NaCl}$

(b)

FIgURE 8: (a) Enzyme activity with different substrates. (b) Protease activity in presence of $\mathrm{NaCl}$ at different $\mathrm{pH}$ values.

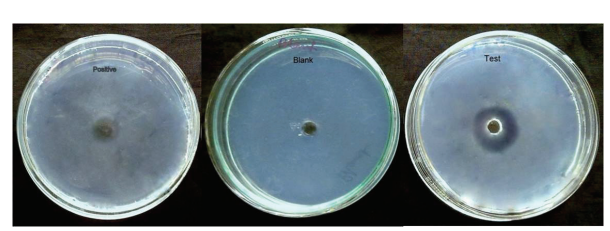

(a)

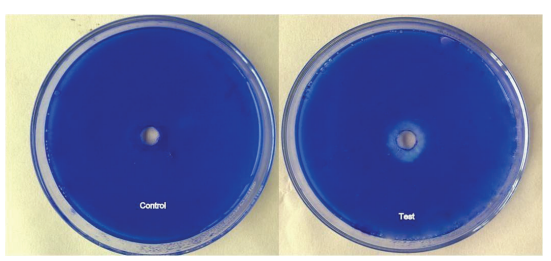

(b)

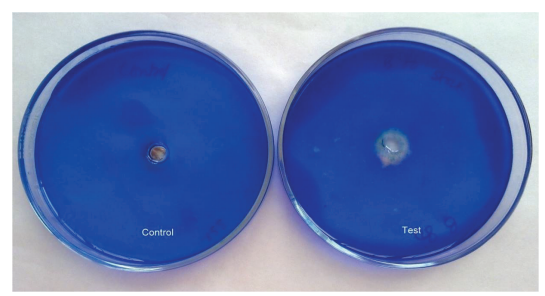

(c)

FIGURE 9: (a) Fibrinolytic activity of the purified metalloprotease against control and positive plates, visible as a clear zone around the well. (b) Collagenolytic activity of purified metalloprotease on collagen plate. (c) Gelatinolytic activity of purified metalloprotease on gelatin plate.

a CD spectrophotometer or a synchrotron radiation circular dichroism (SRCD) beamline [28]. Because the spectra of these molecules in the far UV regions are dominated by the $n-\pi$ and $\pi-\pi^{*}$ transitions of amide groups and are influenced by the geometries of the polypeptide backbones, their spectra are reflective of the different types of secondary structures present [29]. The alpha helix is the most stable of all the secondary structures, and this explains the extreme stable characteristic of the purified enzyme. $\alpha$-helical structure has been reported to contribute in stability of enzyme produced by Pseudomonas aeruginosa strain $K$ in organic solvents, broad range of temperatures, $\mathrm{pHs}$, and metal ions [30]. Alpha helix proteases have been widely studied and reported to understand the diverse functionality of these enzymes [31, 32].

The results obtained from the CD spectroscopy were validated by the tertiary (3D) structure obtained from I-TASSER which also showed presence of more $\alpha$ helices and random coils than $\beta$ strands. I-TASSER is an automated pipeline for protein tertiary structure prediction using multiple threading alignments and iterative structure assembly simulations [19].

The enzyme kinetics study revealed that the enzyme exhibited highest affinity towards casein, with a low $K_{m}$ value suggesting that a minimum amount of enzyme was required for a maximum effect of reaction to occur. Low $K_{m}$ values also suggest that the enzyme is normally saturated with substrate and will act at a constant rate, regardless of variations in the concentration of substrate within the physiological range [33]. Similar low $K_{m}$ values have been reported by Gupta et al. [33] $\left(K_{m}=2.69 \mathrm{mg} / \mathrm{mL}, V_{\max }=3.03 \mu \mathrm{mol} / \mathrm{min}\right)$ and Tang et al. [25] $\left(K_{m}=3.97 \mathrm{mg} / \mathrm{mL}, V_{\max }=7.58 \mu \mathrm{mol} / \mathrm{min}\right)$ towards casein as substrate at $60^{\circ} \mathrm{C}$ indicating its high affinity and efficient catalytic role.

The salt tolerance of the enzyme shows that it is a mild halotolerant metalloprotease. Inouye et al. [34] have reported that $\mathrm{NaCl}$ enhances the catalytic activity and thermal stability of thermolysin. Halotolerant proteases have been reported by Shivanand and Jayaraman [35] and Ningthoujam and Kshetri [36]. Higher salinity may promote binding of a hydrophobic substrate to enzyme or of hydrophobic residues to each other within the enzyme to ensure optimal folding for enzymatic activity. Zinc metalloproteases with fibrinolytic and collagenolytic activity from various Bacillus cereus strains have been reported $[24,37]$.

The enzyme exhibited high stability in various organic solvents. Classical theory suggests that disulfide bonds stabilize proteins by reducing the entropy of the denatured state and hence they have been attributed for the unusual stability properties enzymes [38]. In the light of these findings, we presume that such disulfide bonds existing in the 
metalloprotease enzyme make it resistant against various organic solvents. Also the results show an enhanced enzyme activity in presence of some organic solvents. The general explanations offered include disruption of water structure in the vicinity of the active site formation of higher intrinsic activity resulting in as high as tenfold increase, or presence of high concentrations of miscible organic solvents may induce gross changes in substrate specificity and/or more subtle alterations in chiral selectivity $[39,40]$. Metalloproteases showing stability in wide range of organic solvents have been reported $[24,31]$.

\section{Conclusion}

The enzyme studied in the present work was identified as a zinc metalloprotease as it exhibited 70-93\% matching with zinc metalloprotease from various Bacillus sp. However, on the basis of its amino acid sequence, phylogenetic relationship and predicted tertiary structure, biochemical characteristics, and stability properties, it is established as a novel zinc metalloprotease.

The enzyme exhibited strong fibrinolytic and collagenolytic activity and thus finds a potential use as a natural agent for oral fibrinolytic therapy or thrombosis prevention, in the clinical therapy and in the wound healing process, and as experimental reagents in laboratory work. The enzyme was observed to be mild salt tolerant, while highly stable, in presence of organic solvents. Enzymes with such stability properties are very important from an industrial perspective. Halo tolerant proteases find application in food fermentation where $\mathrm{NaCl}$ is used as preservative. Salt stable collagenases containing ointment are frequently used in clinics to debris wounds. Nonaqueous enzymology has considerably enlarged the use of enzymes for a variety of applications. The unique solvent stability of the enzyme thus establishes it as promising biocatalyst for organic solvent-based enzymatic synthesis.

This enzyme can be exploited for a wide-ranged application in various industries owing to its stability, wide substrate specificity, and fibrinolytic and gelatinolytic properties.

\section{Conflict of Interests}

The authors declare that there is no conflict of interests regarding the publication of this paper.

\section{References}

[1] N. D. Rawlings, A. J. Barrett, and A. Bateman, "MEROPS: the database of proteolytic enzymes, their substrates and inhibitors," Nucleic Acids Research, vol. 40, no. 1, pp. D343D350, 2012.

[2] J.-W. Wu and X.-L. Chen, "Extracellular metalloproteases from bacteria," Applied Microbiology and Biotechnology, vol. 92, no. 2, pp. 253-262, 2011.

[3] K. M. Fukasawa, T. Hata, Y. Ono, and J. Hirose, "Metal preferences of zinc-binding motif on metalloproteases," Journal of Amino Acids, vol. 2011, pp. 1-7, 2011.

[4] L. Liu, M. Ma, Z. Cai, X. Yang, and W. Wang, "Purification and properties of a collagenolytic protease produced by Bacillus cereus MBL13 strain," Food Technology and Biotechnology, vol. 48, no. 2, pp. 151-160, 2010.

[5] A. Jovanovic, R. Ermis, R. Mewaldt, L. Shi, and D. Carson, "The influence of metal salts, surfactants, and wound care products on enzymatic activity of collagenase, the wound debriding enzyme," Wounds, vol. 24, no. 9, pp. 242-253, 2012.

[6] R. Deutzmann, "Structural characterization of proteins and peptides," Methods in Molecular Medicine, vol. 94, pp. 269-297, 2004.

[7] C. Bechara, G. Bolbach, P. Bazzaco et al., "MALDI-TOF mass spectrometry analysis of amphipol-trapped membrane proteins," Analytical Chemistry, vol. 84, no. 14, pp. 6128-6135, 2012.

[8] J. Webster and D. Oxley, "Protein identification by MALDI-TOF mass spectrometry," Methods in Molecular Biology, vol. 800, pp. 227-240, 2012.

[9] K. Ning, D. Fermin, and A. I. Nesvizhskii, "Computational analysis of unassigned high-quality MS/MS spectra in proteomic data sets," Proteomics, vol. 10, no. 14, pp. 2712-2718, 2010.

[10] R. Saxena and R. Singh, "A modeling study by centre composite design in response surface methodology on production parameters optimization for novel metalloprotease by a newly isolated Bacillus cereus b80," Brazilian Journal of Microbiology. In press.

[11] R. Saxena and R. Singh, "Statistical optimization of conditions for protease production from Bacillus sp," Acta Biologica Szegediensis, vol. 54, no. 2, pp. 135-141, 2010.

[12] M. M. Bradford, "A rapid and sensitive method for the quantitation of microgram quantities of protein utilizing the principle of protein dye binding," Analytical Biochemistry, vol. 72, no. 1-2, pp. 248-254, 1976.

[13] U. K. Laemmli, "Cleavage of structural proteins during the assembly of the head of bacteriophage $\mathrm{T}_{4}$," Nature, vol. 227, no. 5259, pp. 680-685, 1970.

[14] B. K. Sørensen, P. Højrup, E. Østergård et al., "Silver staining of proteins on electroblotting membranes and intensification of silver staining of proteins separated by polyacrylamide gel electrophoresis," Analytical Biochemistry, vol. 304, no. 1, pp. 3341, 2002.

[15] F. L. Garcia-Carreno, L. E. Dimes, and N. F. Haard, "Substrategel electrophoresis for composition and molecular weight of proteinases or proteinaceous proteinase inhibitors," Analytical Biochemistry, vol. 214, no. 1, pp. 65-69, 1993.

[16] M. A. Larkin, G. Blackshields, N. P. Brown et al., "Clustal W and Clustal X version 2.0," Bioinformatics, vol. 23, no. 21, pp. 29472948, 2007.

[17] T. Astrup and S. Müllertz, "The fibrin plate method for estimating fibrinolytic activity," Archives of Biochemistry and Biophysics, vol. 40, no. 2, pp. 346-351, 1952.

[18] G. Datta, A. Dong, J. Witt, and A. T. Tu, "Biochemical characterization of basilase, a fibrinolytic enzyme from Crotalus basiliscus basiliscus," Archives of Biochemistry and Biophysics, vol. 317, no. 2, pp. 365-373, 1995.

[19] A. Roy, A. Kucukural, and Y. Zhang, "I-TASSER: a unified platform for automated protein structure and function prediction," Nature Protocols, vol. 5, no. 4, pp. 725-738, 2010.

[20] Y. Zhang and J. Skolnick, "Scoring function for automated assessment of protein structure template quality," Proteins: Structure, Function and Genetics, vol. 57, no. 4, pp. 702-710, 2004.

[21] W. W. Ward and G. Swiatek, "Protein purification," in Current Analytical Chemistry, vol. 5, Bentham Science, 2009. 
[22] M. Hedhammar, A. E. Karlstron, and S. Hober, Chromatographic Methods for Protein Purification, Royal Institute of Technology, Stockholm, Sweden, 2006.

[23] R. A. Abusham, R. N. Z. R. A. Rahman, A. Salleh, and M. Basri, "Optimization of physical factors affecting the production of thermo-stable organic solvent-tolerant protease from a newly isolated halo tolerant Bacillus subtilis strain Rand," Microbial Cell Factories, vol. 8, article 20, 2009.

[24] L. Manni, K. Jellouli, O. Ghorbel-Bellaaj et al., "An oxidantand solvent-stable protease produced by bacillus cereus SV1: application in the deproteinization of shrimp wastes and as a laundry detergent additive," Applied Biochemistry and Biotechnology, vol. 160, no. 8, pp. 2308-2321, 2010.

[25] X.-Y. Tang, B. Wu, H.-J. Ying, and B.-F. He, "Biochemical properties and potential applications of a solvent-stable protease from the high-yield protease producer Pseudomonas aeruginosa PT121," Applied Biochemistry and Biotechnology, vol. 160, no. 4, pp. 1017-1031, 2010.

[26] S. D. Maleknia and R. Johnson, "Mass spectrometry of amino acids and proteins," in Amino Acids, Peptides and Proteins in Organic Chemistry: Analysis and Function of Amino Acids and Peptides, A. B. Hughes, Ed., vol. 5, Wiley-VCH, Weinheim, Germany, 2011.

[27] M. L. Nielsen, M. M. Savitski, and R. A. Zubarev, "Extent of modifications in human proteome samples and their effect on dynamic range of analysis in shotgun proteomics," Molecular \& Cellular Proteomics, vol. 5, no. 12, pp. 2384-2391, 2006.

[28] D. P. Klose, B. A. Wallace, and R. W. Janes, "DichroMatch: a website for similarity searching of circular dichroism spectra," Nucleic Acids Research, vol. 40, no. 1, pp. W547-W552, 2012.

[29] L. Whitmore and B. A. Wallace, "Protein secondary structure analyses from circular dichroism spectroscopy: methods and reference databases," Biopolymers, vol. 89, no. 5, pp. 392-400, 2008.

[30] R. N. Z. R. A. Rahman, A. B. Salleh, M. Basri, and C. F. Wong, "Role of $\alpha$-helical structure in organic solvent-activated homodimer of elastase strain K," International Journal of Molecular Sciences, vol. 12, no. 9, pp. 5797-5814, 2011.

[31] A. Ruf, M. Stihle, J. Benz, M. Schmidt, and H. Sobek, "Structure of Gentlyase, the neutral metalloprotease of Paenibacillus polymyxa," Acta Crystallographica Section D: Biological Crystallography, vol. 69, part 1, pp. 24-31, 2013.

[32] T. Yamaguchi, K. Sahara, H. Bando, and S.-I. Asano, "Intramolecular proteolytic nicking and binding of Bacillus thuringiensis Cry8Da toxin in BBMVs of Japanese beetle," Journal of Invertebrate Pathology, vol. 105, no. 3, pp. 243-247, 2010.

[33] A. Gupta, I. Roy, S. K. Khare, and M. N. Gupta, "Purification and characterization of a solvent stable protease from Pseudomonas aeruginosa PseA," Journal of Chromatography A, vol. 1069, no. 2, pp. 155-161, 2005.

[34] K. Inouye, K. Kuzuya, and B. Tonomura, "Sodium chloride enhances markedly the thermal stability of thermolysin as well as its catalytic activity," Biochimica et Biophysica Acta, vol. 1388, no. 1, pp. 209-214, 1998.

[35] P. Shivanand and G. Jayaraman, "Production of extracellular protease from halotolerant bacterium, Bacillus aquimaris strain VITP4 isolated from Kumta coast," Process Biochemistry, vol. 44, no. 10, pp. 1088-1094, 2009.

[36] D. S. Ningthoujam and P. Kshetri, "A thermostable alkaline protease from a moderately halo-alkalithermotolerant Bacillus
Subtilis strain SH1," Australian Journal of Basic and Applied Sciences, vol. 4, no. 10, pp. 5224-5233, 2010.

[37] W. A. Hassanein, E. Kotb, N. M. Awny, and Y. A. El-Zawahry, "Fibrinolysis and anticoagulant potential of a metallo-protease produced by Bacillus subtilis K42," Journal of Biosciences, vol. 36, no. 5, pp. 1-7, 2011.

[38] H. Ogino, S. Tsuchiyama, M. Yasuda, and N. Doukyu, "Enhancement of the aspartame precursor synthetic activity of an organic solvent-stable protease," Protein Engineering, Design and Selection, vol. 23, no. 3, pp. 147-152, 2010.

[39] Y. L. Khmnelnitsky, A. V. Levashov, N. L. Klyachko, and K. Martinek, "Engineering biocatalytic systems in organic media with low water content," Enzyme and Microbial Technology, vol. 10, no. 12, pp. 710-724, 1988.

[40] D. A. Cowan, "Thermophilic proteins: stability and function in aqueous and organic solvents," Comparative Biochemistry and Physiology A: Physiology, vol. 118, no. 3, pp. 429-438, 1997. 

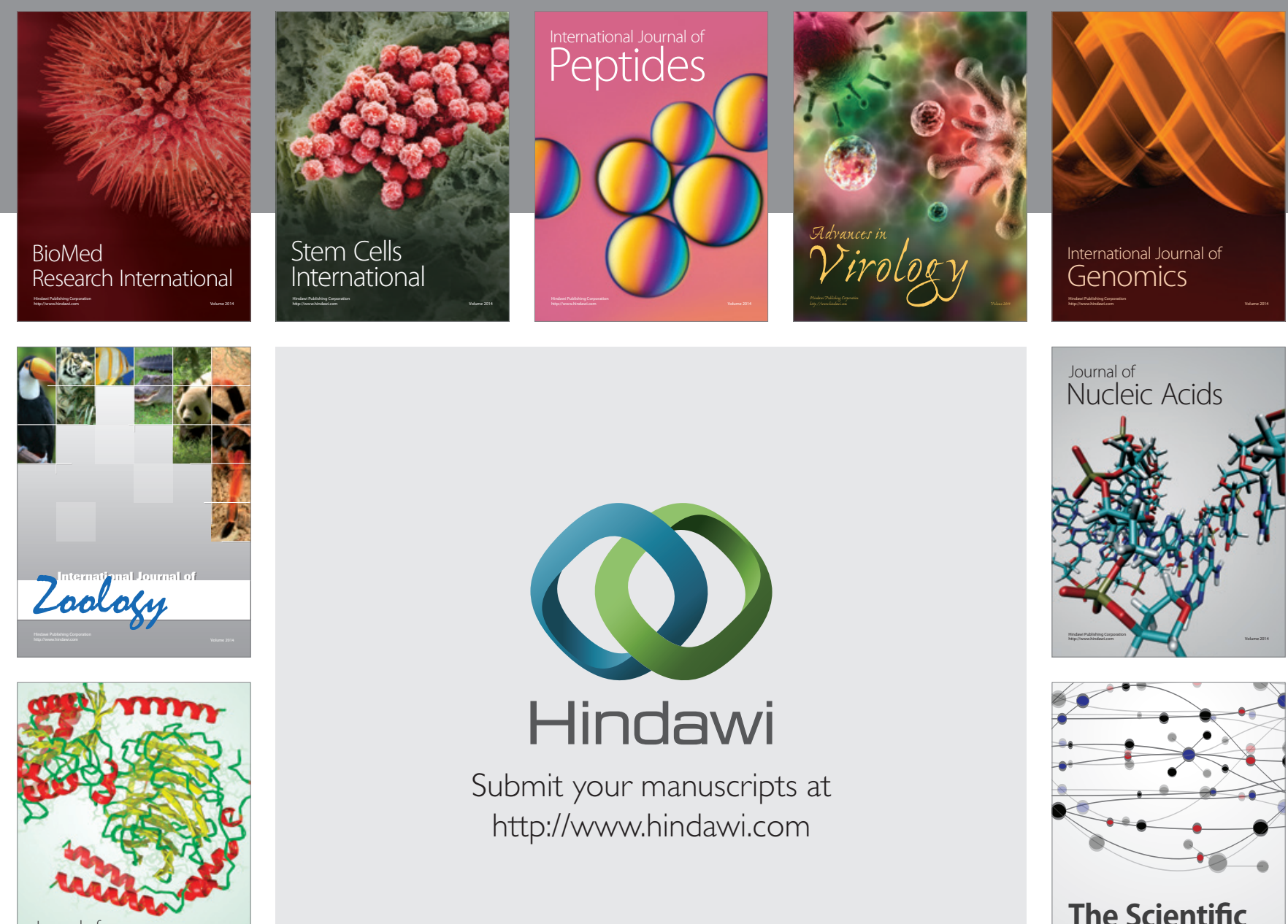

Submit your manuscripts at

http://www.hindawi.com

Journal of
Signal Transduction
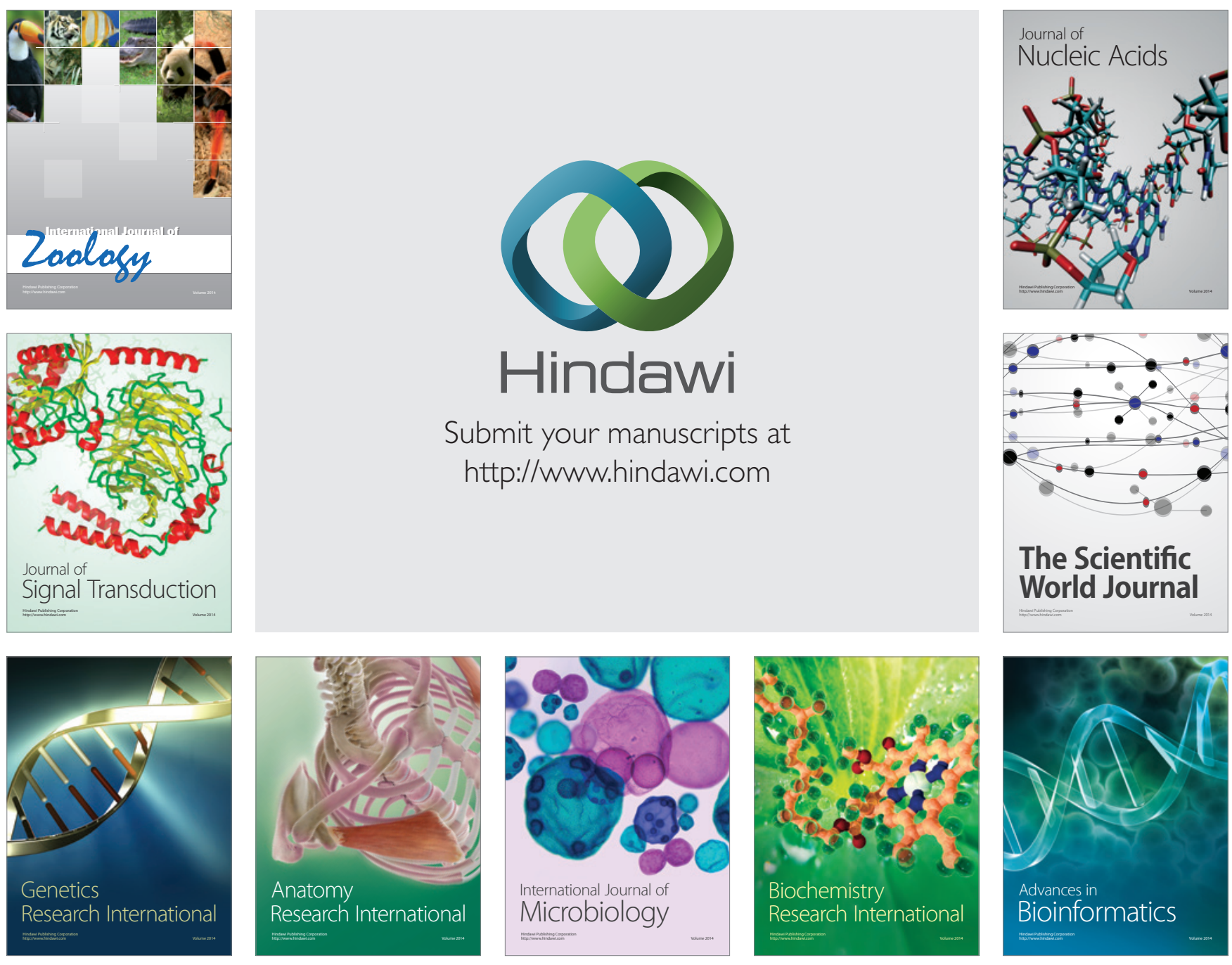

The Scientific World Journal
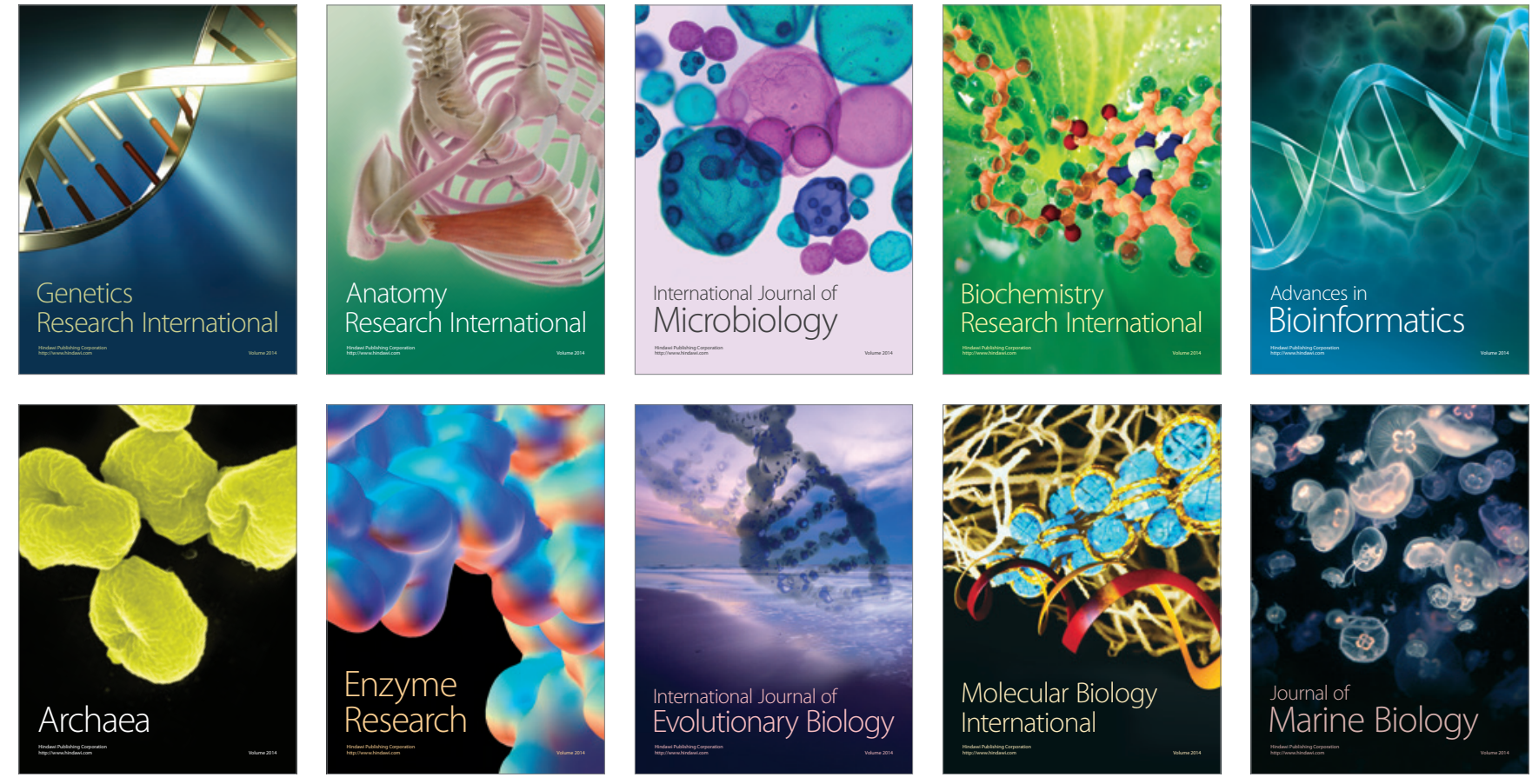